\title{
Recent advances in metabolic and bariatric surgery [version 1;
}

\section{peer review: 2 approved]}

\author{
Vance L. Albaugh (iD, C. Robb Flynn, Robyn A. Tamboli, Naji N. Abumrad
}

Department of Surgery, Vanderbilt University Medical Center, Nashville, Tennessee, 37232, USA

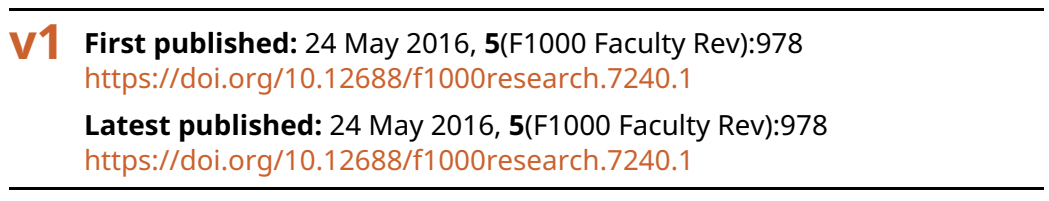

\section{Abstract}

Obesity and its associated medical conditions continue to increase and add significant burden to patients, as well as health-care systems, worldwide. Bariatric surgery is the most effective treatment for severe obesity and its comorbidities, and resolution of diabetes is weight loss-independent in the case of some operations. Although these weight-independent effects are frequently described clinically, the mechanisms behind them are not well understood and remain an intense area of focus in the growing field of metabolic and bariatric surgery. Perceptions of the mechanisms responsible for the beneficial metabolic effects of metabolic/bariatric operations have shifted from being mostly restrictive and malabsorption over the last 10 to 15 years to being more neuro-hormonal in origin. In this review, we describe recent basic and clinical findings of the major clinical procedures (adjustable gastric banding, vertical sleeve gastrectomy, Roux-en-Y gastric bypass, and biliopancreatic diversion) as well as other experimental procedures (ileal interposition and bile diversion) that recapitulate many of the metabolic effects of these complex operations in a simpler fashion. As the role of bile acids and the gut microbiome on metabolism is becoming increasingly well described, their potential roles in these improvements following metabolic surgery are becoming better appreciated. Bile acid and gut microbiome changes, in light of recent developments, are discussed in the context of these surgical procedures, as well as their implications for future study.

\section{Keywords}

Metabolic surgery, Bariatric surgery , Morbid obesity , adjustable gastric banding, vertical sleeve gastrectomy, Roux-en-Y gastric bypass, biliopancreatic diversion, ileal interposition, bile diversion

\section{Open Peer Review}

Approval Status

1

2

version 1

24 May 2016

Faculty Reviews are review articles written by the prestigious Members of Faculty Opinions. The articles are commissioned and peer reviewed before publication to ensure that the final, published version is comprehensive and accessible. The reviewers who approved the final version are listed with their names and affiliations.

1. Alfonso Torquati, Rush University Medical Center, Chicago, USA

2. Mario Musella, Federico II University of Naples, Naples, Italy Any comments on the article can be found at the end of the article. 
Corresponding author: Naji N. Abumrad (naji.abumrad@vanderbilt.edu)

Competing interests: The authors declare that they have no competing interests.

Grant information: The National Institute of Diabetes and Digestive and Kidney Diseases supported this work through the following grants: F32DK103474 (VLA), R01DK091748, R01DK070860, R01 DK105847, R01DK100431, R24DK093421-01A1, and DK058404 (Vanderbilt Digestive Disease Research Center), DK20593 (Vanderbilt Diabetes Research and Training Center), and 1UL1RR024975 (Vanderbilt Clinical and Translational Science Award).

The funders had no role in study design, data collection and analysis, decision to publish, or preparation of the manuscript.

Copyright: $\Subset 2016$ Albaugh VL et al. This is an open access article distributed under the terms of the Creative Commons Attribution License, which permits unrestricted use, distribution, and reproduction in any medium, provided the original work is properly cited.

How to cite this article: Albaugh VL, Flynn CR, Tamboli RA and Abumrad NN. Recent advances in metabolic and bariatric surgery [version 1; peer review: 2 approved] F1000Research 2016, 5(F1000 Faculty Rev):978 https://doi.org/10.12688/f1000research.7240.1

First published: 24 May 2016, 5(F1000 Faculty Rev):978 https://doi.org/10.12688/f1000research.7240.1 


\section{Introduction}

Obesity is a significant health-care problem with few treatment options, many of which are only minimally effective in the long term. Medical therapy consisting of intensive lifestyle modification (that is, diet, exercise, and behavioral therapy) fails to maintain significant long-term weight loss. Although medical intervention can lead to modest weight loss in select patients ${ }^{1}, 5-10 \%$ weight loss in a morbidly obese individual still leaves that patient with significant cardiometabolic risk ${ }^{2,3}$.

Metabolic and bariatric surgery (in this review, the phrase "metabolic and bariatric surgery" refers to a single entity) is recognized as the most effective treatment for obesity and its associated comorbidities, such as type 2 diabetes $^{4-7}$, and its usage continues to increase with the increasing prevalence of obesity and metabolic disease. Early studies from Pories and colleagues ${ }^{8}$ and others ${ }^{9,10}$ in gastric bypass patients described diabetes resolving almost immediately after surgery. Even though this effect was described more than 30 years ago ${ }^{8,11}$, its complex underlying mechanisms remain an intense research focus. Multiple reviews and meta-analyses have confirmed a diabetes resolution rate of approximately $80 \%{ }^{12-14}$ and also provide evidence that operating in patients with a body mass index of less than $35 \mathrm{~kg} / \mathrm{m}^{2}$ may be warranted as well for nonobese diabetics $^{15-19}$. Overall, the benefits of bariatric and metabolic surgery continue to be better described, particularly the decreases in cardiovascular disease and cancer mortality ${ }^{20,21}$. With the alleviation of diabetes and other comorbidities, it is not surprising that bariatric surgery also exhibits cost savings compared with chronic medical treatment of these diseases ${ }^{20,22-24}$.

Our aim herein is not to focus on the anatomic differences of the particular operations per se but instead to highlight the discoveries and new questions each procedure has provided over about the last 5 years. The field of metabolic and bariatric surgery has a rich history, although our understanding of how these operations lead to their beneficial effects has significantly changed over the last 10 to 15 years. Operations that were originally intended to produce weight loss through combinations of gastric restriction or malabsorption (or both) clearly have metabolic benefits that are independent from either one of these previously long-held beliefs of their mechanism of action. The historical bile diversion and ileal interposition operations are scientifically in vogue once again and are helping to examine the complex role of bile acids in metabolic regulation. We have focused on the insights from the most popular procedures clinically and experimentally, including gastric banding, vertical sleeve gastrectomy (VSG), Roux-en-Y gastric bypass (RYGB), biliopancreatic diversion (BPD), ileal interposition, and bile diversion. Importantly, we have emphasized many of the species-specific changes that must be considered when translating findings to a clinical context. The role of bile acids and the gut microbiome and their potential interaction is discussed. For a comprehensive discussion of the rapidly growing field of metabolic and bariatric surgery, we direct the reader to this excellent review ${ }^{25}$.

\section{Purely restrictive operations}

Adjustable gastric banding and gastric balloons

The contribution of gastric restriction to the efficacy of bariatric surgery is an area that has been well studied clinically and experimentally. The adjustable gastric band (Figure 1) and gastric

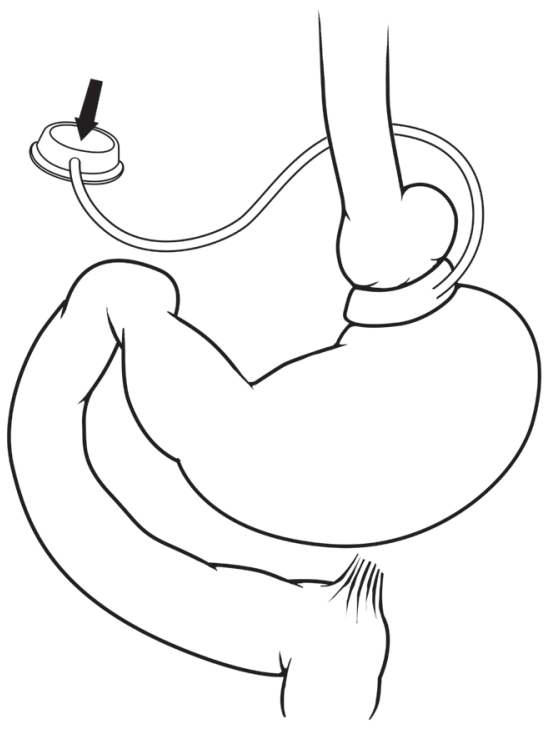

Figure 1. Adjustable gastric banding. In this procedure, an external ring is placed around the proximal portion of the stomach and has a balloon that lines the inside portion of the ring. The inflatable balloon is connected to a port in the subcutaneous tissue of the abdomen that allows the balloon volume, and therefore the amount of gastric restriction, to be adjusted.

balloons are two procedures that purely decrease the capacity of the stomach, by either an adjustable external compressive device (that is, the adjustable gastric band) or merely taking up space within the stomach (that is, the gastric balloon). Over the last decade, adjustable gastric banding has continued to fall from its peak clinical usage in 2008 to currently comprising only $10 \%$ of bariatric procedures worldwide $^{26}$. This decline is due to the relative ineffectiveness of banding for long-term weight loss and reduced comorbidity compared to other bariatric procedures. Consistent with this trend and clinical findings, gastric banding has been modeled in rodents ${ }^{27-29}$ and has been shown to be less effective for long-term weight loss or improvements in glucose tolerance compared with other procedures (for example, RYGB and BPD) that have additional hormonal or malabsorptive characteristics or both greater and more durable effects. In rodent models, gastric banding is purely restrictive and does not confer any additional benefits beyond restriction of food intake ${ }^{29-33}$. Banding exerts a temporary weight loss that is compensated for over the course of several weeks ${ }^{27}$. The delayed resolution of diabetes or other metabolic comorbid conditions is greater with, and attributable to, weight loss secondary to decreased food intake and not direct neuro-hormonal effects ${ }^{34,35}$.

Similarly, gastric balloons have recently been approved in the US, although they have been used in Europe for over a decade ${ }^{36}$. The science behind the balloon is similar to gastric banding in that the balloons are meant to simulate a false sense of gastric distention and promote satiety even after consumption of a minuscule amount of food. Again, similar to the banding procedure, these devices in theory are purely restrictive; however, as they become more popularly used in Europe and the US, further investigation into the potential changes in hormonal or metabolic effects can be studied $^{37,38}$. 


\section{More than gastric restriction: operations with hormonal effects}

Without a doubt the most exciting advancements in the field of metabolic and bariatric surgery over the last decade have been the identification of mechanisms that have challenged the long-held beliefs that "bariatric" surgical procedures induce weight loss purely through a combination of gastric restriction or nutrient malabsorption, or both. Neural, hormonal, and other nutrient signaling pathways that have previously been unrecognized may be mediating many of the metabolic benefits of these surgical procedures. We examine three of these operations to help highlight these novel and alternative mechanisms in the following section.

\section{Vertical sleeve gastrectomy}

The vertical sleeve gastrectomy is a surgical procedure that decreases gastric volume by approximately $70 \%$ with excision of a large portion of stomach along the greater curvature (Figure 2). As mentioned above, clinical and experimental evidence has demonstrated that gastric restriction alone is not effective as a long-term solution for obesity or its comorbidities. When VSG was first introduced, it was deemed to be a purely restrictive procedure; however, this view has been transformed on the basis of clinical and experimental observations. With better weight loss and metabolic outcomes compared with gastric banding, VSG has increased in usage over the last decade and become almost as popular as RYGB ${ }^{26}$. However, whether VSG provides similar remission to obesity and diabetes long-term has yet to be determined. The ongoing STAMPEDE trial (Surgical Therapy And Medications Potentially Eradicate Diabetes Efficiently $)^{4}$, the first prospective randomized clinical trial designed to compare both VSG and RYGB to intensive lifestyle modification alone, is not designed to make direct comparisons between VSG and RYGB. Regardless, the data from the STAMPEDE trial should give us rough insight into how well VSG compares to intensive lifestyle intervention and medical therapy in the long term.

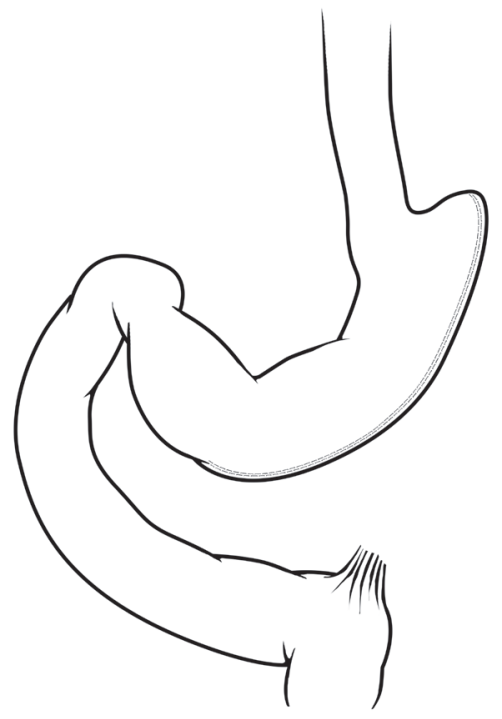

Figure 2. Vertical sleeve gastrectomy. A majority of the greater curvature is excised in this procedure, creating a tube-like stomach with a marked reduction in gastric capacity.
Aside from its clinical usage, VSG has been described in multiple rodent studies and has several interesting physiologic effects that cannot be explained by restriction alone. In fact, data have directly challenged the notion that VSG involves any intrinsic gastric restriction at all. In studies by Grayson and colleagues ${ }^{39}$, lactating female rats that had previously received a VSG or sham operation were both able to increase their food intake in response to lactation without any evidence of food intake restriction in the VSG rats that were lactating-one of the most energy-demanding processes physiologically when dams routinely double or even triple their food intake ${ }^{40}$. Initially, VSG was thought to work by excision of the ghrelin-producing portion of the stomach ${ }^{41}$. Indeed, circulating ghrelin concentrations are significantly decreased up to a year after $\mathrm{VSG}^{42}$. Interestingly, even in the absence of intestinal rearrangement, VSG is associated with increased secretion of the distal intestinal hormones GLP-1 and peptide YY (PYY) ${ }^{43-45}$. Studies using rodent models of VSG have examined the contribution of these hormonal changes and other mechanisms to VSG efficacy. Mice with genetic deletion of ghrelin or the GLP-1 receptor continue to show weight loss following $\mathrm{VSG}^{46,47}$, suggesting that isolated changes in these hormones cannot explain the efficacy of the procedure. Unlike ghrelin and GLP-1 receptor knockout mice, though, mice deficient in the bile acid receptor FXR (farnesoid $\mathrm{X}$ receptor) have completely abrogated effects of VSG while on a high-fat diet $^{48}$, thus implicating FXR as a major target of VSG. Consistent with this bile acid receptor dependency, VSG is associated with increased plasma bile acid concentrations in the mouse ${ }^{49}$, but whether the same holds true in humans is not year clear ${ }^{50}$. Stefater and colleagues ${ }^{25}$ examined the effects of VSG compared with diet-induced obesity, pair-fed, or chow-fed control rats. In that study, total bile acids were increased by VSG or pair-feeding by unknown mechanisms, which began to approach the higher concentrations of total bile acids reported in the chow-fed controls. How FXR signaling is altered by bariatric surgery and what other pathways may be affected by VSG remain unclear, although a number of other VSG-related effects require further study, including changes to taste preference similar to RYGB as well as changes in intestinal triglyceride metabolism ${ }^{51-54}$.

Roux-en-Y gastric bypass and biliopancreatic diversion The RYGB (Figure 3) and BPD (Figure 4) operations combine significant intestinal rearrangement with gastric restriction. Each procedure involves creation of a smaller stomach pouch while diverting nutrient flow to varying distal segments of the intestine. The gastric restrictive component is typically less with BPD but diversion of biliopancreatic secretions is more distal, compared with RYGB. Both RYGB and BPD were originally thought to cause weight loss through a combination of malabsorption and gastric restriction. From clinical practice, we know that bariatric surgical patients are at higher risk for certain micronutrient deficiencies, highly suggestive of an intrinsic malabsorptive component leading to weight loss after these procedures ${ }^{55-57}$. Compared with RYGB patients, BPD patients tend to have more nutritional and gastrointestinal (GI) side effects ${ }^{58}$, which may indicate a more severe malabsorptive phenotype. Regardless, both operations produce improvements in diabetes/insulin resistance ${ }^{59-62}$. Several studies have attempted to determine the magnitude of malabsorption following these procedures clinically and experimentally. In terms of macronutrient malabsorption, animal studies suggest a higher 


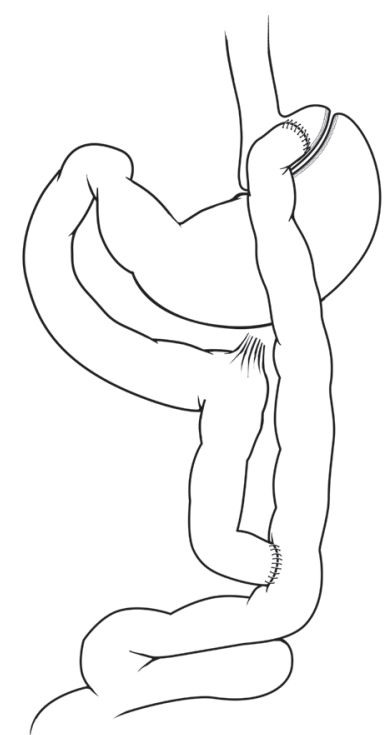

Figure 3. Roux-en-Y gastric bypass. The stomach is divided, creating a small gastric pouch that is connected through a gastrojejunostomy to a distal segment of jejunum, which forms the Roux limb of the procedure. The remainder of the stomach is referred to as the "gastric remnant" and drains into the bypassed portion of bowel, referred to as the "biliopancreatic limb". Bowel continuity is restored for the biliopancreatic limb by a jejuno-jejunostomy that creates the " $Y$ " configuration of the operation. Thus, ingested nutrients proceed rapidly through the stomach pouch and move immediately into the jejunal Roux limb in the absence of bile and pancreatic secretions. Bile and pancreatic secretions drain via the biliopancreatic limb and then mix with the chyme/nutrients at the point of the jejuno-jejunostomy.

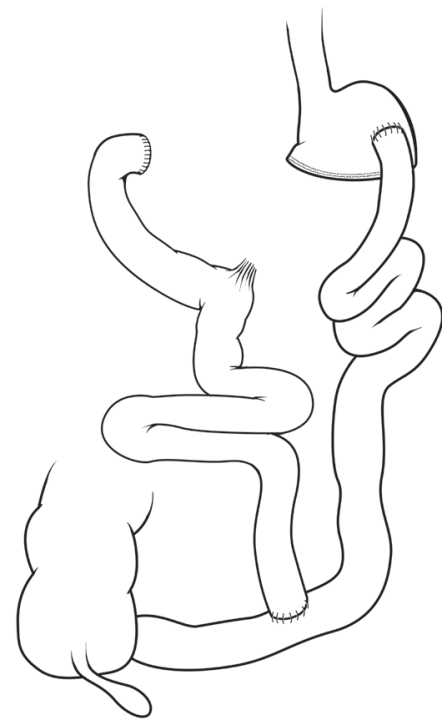

Figure 4. Biliopancreatic diversion. This is a procedure that effectively diverts bile and pancreatic secretions to the distal bowel for mixing with nutrients/chyme, typically much further distal than a Roux-en-Y gastric bypass. This procedure can be performed with or without a partial gastrectomy and is also referred to as a duodenal switch; the "switch" is the diversion of bile and pancreatic secretions from nutrient flow. degree of malabsorption in RYGB/BPD models, which could contribute to significant weight loss ${ }^{63,64}$. However, this degree of malabsorption is not consistently observed in practice, and several clinical studies show frank macronutrient malabsorption, minimal macronutrient malabsorption, or no macronutrient malabsorption at all ${ }^{65-68}$. Both nutrient and macronutrient malabsorption appear to be much more easily observed in the BPD models compared with RYGB ${ }^{65,69}$. Collectively, macronutrient malabsorption appears to play a much greater role in the case of BPD than RYGB in the weight loss observed in these patients clinically. However, the complex intestinal rearrangement, altered nutrient absorption, and physical separation of biliopancreatic secretions from nutrients in these operations may alter the intestinal nutrient milieu to explain what drives many of the hormonal and histologic changes ${ }^{70}$ observed in these procedures.

Given the anatomic changes with RYGB and BPD, two opposing hypotheses-referred to as the "foregut hypothesis" and the "hindgut hypothesis" - arose in the field. The foregut hypothesis posits that an unknown factor-neural or hormonal or bothoriginates from the bypassed intestinal region in RYGB/BPD that promotes insulin resistance. Thus, bypass of that segment is associated with metabolic improvements. There is considerable evidence in support of this hypothesis, proposed as early as the 1980 s by Scopinaro and colleagues ${ }^{71}$, although the identity of such a factor remains elusive ${ }^{72,73}$. Two studies examined the foregut hypothesis directly in RYGB patients with gastrostomy tubes in the gastric remnant ${ }^{74,75}$. Hansen and colleagues ${ }^{74}$ found that reintroduction of nutrients into the excluded foregut in the first 6 weeks after RYGB did not reverse improvement in glucose responses, whereas Pournaras and colleagues ${ }^{75}$ found reversal between 9 and 24 months after RYGB. Differences between these two studies could be related to early-versus-late post-operative effects or possible enteral feeding prior to testing in the latter study. Animal studies have also had mixed results, showing that duodenal nutrient exclusion is associated with villous hyperplasia but that improvements in glucose tolerance, weight loss, or incretins are mixed and may depend heavily on strain/genetic background ${ }^{76-79}$. Conversely, the "hindgut hypothesis" posits that the more rapid delivery of nutrients to the hindgut stimulates either neural or hormonal factors (or both) that lead to the metabolic benefits and weight loss. Within the first month after surgery, concomitant increases in postprandial GLP-1 and insulin secretion and an enhanced incretin effect are observed and have positioned GLP-1 as the prime mediator of improved glucose homeostasis after the procedure. Recent data using GLP-1 receptor antagonists have challenged a dominant role for GLP-1. Although these data indicate that the increased GLP-1 contributes to the increased insulin secretion, this does not translate into improved glucose homeostasis ${ }^{80}$. It is somewhat unfortunate that these opposing theories arose, because the field has come to appreciate that there are likely components of each that could potentially be at work following RYGB and BPD.

Aside from foregut bypass, a number of anatomic/histologic changes are associated with the intestinal rearrangement that can be potentially linked to the metabolic changes. Cell proliferation and villous surface area are increased in the Roux limb of RYGB in humans, as are expression levels of genes suggestive of increased energy demands ${ }^{81}$. A working hypothesis in rats is that Roux limb 
hypertrophy, secondary to energetic demands on the jejunum, results in increased nutrient uptake following RYGB, making the Roux limb a significant contributor to glucose homeostasis. This is evident by increased basolateral glucose uptake of the Roux limb in the post-absorptive state with corresponding changes in glucose transporters on immunohistologic analysis ${ }^{82}$. Consistent with this intestinal hypertrophy hypothesis, other procedures have also shown changes in intestinal histology and increased L-cell populations with concomitant changes in L-cell hormonal responses (that is, GLP-1 and PYY) $)^{64,83,84}$. However, histologic changes also occur in the common channel (that is, distal ileum) that could represent hypertrophy secondary to undigested luminal nutrients ${ }^{85}$.

Besides the improvements in insulin sensitivity/glucose homeostasis and weight loss observed with RYGB, nutrient signaling within the GI tract to alter taste or other metabolic processes is significantly changed by these operations. Several studies have demonstrated altered taste preference for lipid or glucose solutions in humans and animals after RYGB ${ }^{52,86-88}$. These findings appear to reflect changes in central reward pathways, but whether this reflects direct central effects or actions of peripheral signals needs to be determined $^{88-91}$. Additionally, similar neural sensing mechanisms operating via the vagus nerve have been implicated in luminal nutrient sensing, which adds another layer of complexity between the neural and hormonal regulation that is changed by RYGB and potentially other bariatric operations. Further studies are needed to identify these mechanisms, as the role of the vagus nerve in these effects remains unclear ${ }^{92-94}$.

Although most of the focus has been placed on the intestines, considerable evidence indicates that negative energy balance may also have beneficial metabolic effects after RYGB. In the immediate post-operative period, significant caloric restriction contributes to the early improvements in glucose metabolism ${ }^{95-97}$. Within the first month after surgery, improvements in hepatic insulin sensitivity are evident ${ }^{98,99}$, indicating an important contribution of the liver in mediating the weight loss-independent effects of RYGB. On the other hand, an improvement in peripheral insulin sensitivity, which mediates glucose disposal after a meal, occurs later and is related to the ensuing weight loss ${ }^{99-101}$. It has been debated whether an increase in energy expenditure is responsible for weight loss postoperatively in these patients. Recent evidence suggests that resting energy expenditure is increased in mice ${ }^{63,102}$ as well as rats ${ }^{103,104}$ following RYGB. Unlike animal data, human studies using appropriate methodology (that is, regression modeling ${ }^{105-107}$ ) do not support any increases in energy expenditure following RYGB ${ }^{108,109}$. In fact, the massive weight loss of RYGB occurs in the setting of metabolic adaptation (decreased energy demands greater than expected for the degree of weight loss), suggesting the contribution of hormonal or neuronal factors (or both) in the anorectic effect $^{110}$. The effects of RYGB on energy expenditure appear to be contrary to those observed in BPD, which Scopinaro and colleagues have reported ${ }^{111}$. Overall, when examining the metabolic and body weight changes observed both acutely and chronically by RYGB and comparing those with BPD, researchers are tempted to speculate that the BPD operation represents an extreme physiologic response. A response of this magnitude tends to make sense given the apparent effects of BPD on energy expenditure, malabsorption, and long-term body weight, which are more easily observed with that procedure compared with RYGB.

\section{Experimental metabolic operations without gastric restriction}

lleal interposition

The ileal interposition (Figure 5), also previously referred to as "ileal transposition", has been an insightful procedure used to examine the mechanisms underlying altered nutrient flow after RYGB or BPD. The procedure involves taking a neurovascular intact segment of near-terminal ileum and interposing it just distal to the ligament of Treitz, effectively producing a model simulating rapid hindgut delivery like RYGB or BPD, but without any gastric restriction. Koopmans and colleagues ${ }^{12}$ first identified that ileal interposition surprisingly led to decreased food intake in obese rats, which the authors attributed to an "over-stimulated ileum". In most cases, however, these changes in food intake or body weight are either negligible or modest and this may explain why they are not uniformly detectable-indicating potential importance of genetic background (that is, animal strain) or feeding/housing methods in rodent studies ${ }^{113-116}$. Moreover, these changes appear to be heavily dependent on the length of the ileal segment interposed; longer interposed segments have more robust metabolic effects that could account for variability of findings ${ }^{117}$. Consistent with this over-stimulated ileal hypothesis, the ileal interposition has profound effects on glucose homeostasis as well as GI hormone secretion and bile acid metabolism similar to RYGB, BPD, and VSG. Weight-independent improvements in glucose homeostasis in rats are secondary to improved skeletal muscle glucose uptake and insulin signaling via $\mathrm{Akt}^{113}$. These benefits persist in monogenic and polygenic rat models of obesity or diabetes, or both ${ }^{113,114}$. The interposition procedure is also associated with

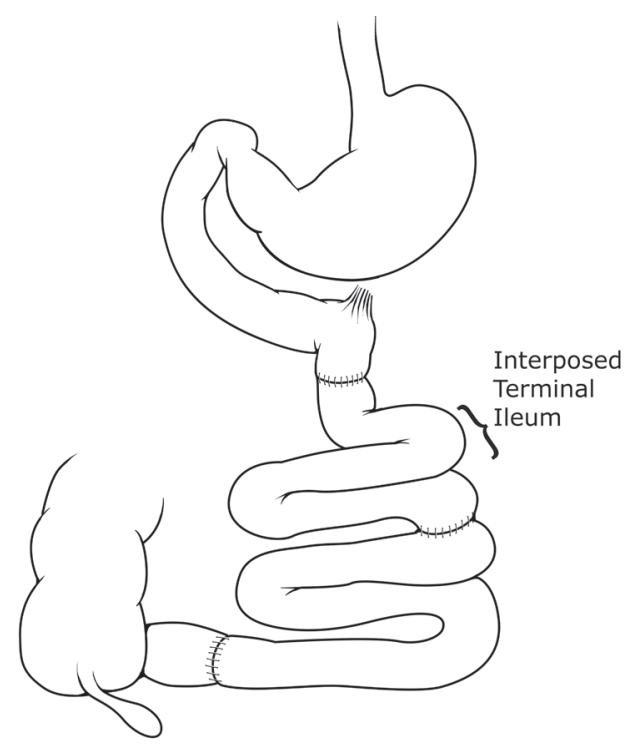

Figure 5. Ileal interposition. A neurovascular intact segment of distal or near-terminal ileum is interposed in the proximal jejunum near the ligament of Treitz. The distal jejunum is then re-anastomosed to the small segment of ileum proximal to the ileocecal valve to re-establish bowel continuity. 
increased expression and secretion of ileal hormones (that is, GLP-1 and GIP) $)^{113,115,116}$ that correspond to increased enteroendocrine cell numbers ${ }^{118}$.

Aside from ileal hormones, ileal interposition causes marked elevations in circulating bile acids ${ }^{113,116}$, the mechanism of which remains unclear. However, both basal and nutrient-stimulated bile acid concentrations are a common finding after bariatric operations. In this regard, bile acids are recognized players in the regulation of glucose and lipid metabolism through the FXR and TGR5 receptors, respectively. It is tempting to speculate that activation of those receptors could improve glucose tolerance and enhance insulin sensitivity.

The mechanisms responsible for the observed elevations in plasma bile acid concentrations following ileal interposition remain unclear. Strader and colleagues ${ }^{119}$ suggested that the beneficial effects of ileal interposition come from nutrient or bile exposure of the interposed ileal segment at much higher concentrations, thus overwhelming the transposed segment and subsequently causing compensatory changes to the "neo-ileum". In rats, following ileal interposition the apical sodium bile acid transporter is decreased ( $95 \%)$ in the interposed ileal segment, although the cytosolic transporter is increased. In those same animals, however, the most distal segments of intestine (that is, the remaining or neo-ileum and/or colon) had robust increases in expression of these transporters ${ }^{119}$.

\section{Bile diversion}

Bile diversion (Figure 6) was an experimental surgical technique developed in the $1960 \mathrm{~s}^{120,121}$ for surgical management of hypercholesterolemia. The proposed mechanism of the procedure was

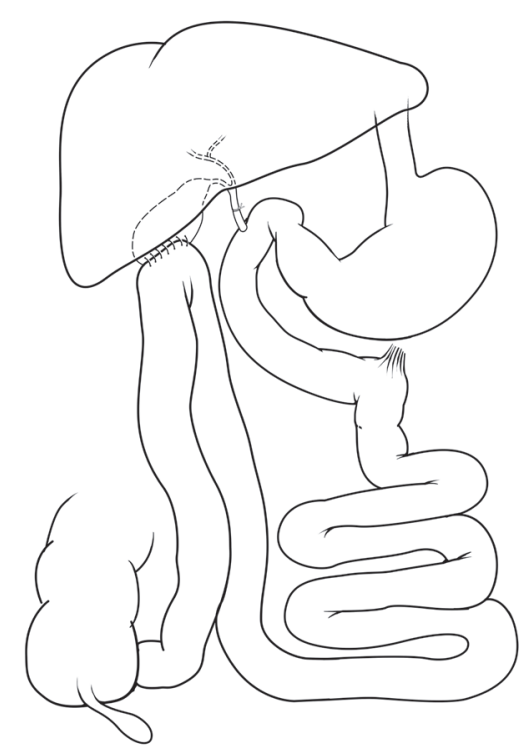

Figure 6. Bile diversion. In the absence of any gastric restriction, the common bile duct is ligated proximal to the pancreatic duct and an anastomosis is created between a portion of ileum and the gallbladder. Pancreatic secretions follow their normal course and drain into the duodenum, but biliary secretions are diverted to the portion of ileum connected directly to the gallbladder. to prevent bile salts from mixing with intestinal contents prior to reaching the colon, and thus cholesterol (and other lipid) absorption would be significantly less. The bile diversion procedure paralleled the development of the jejunal-ileal and ileal bypasses pioneered by Buchwald and Gebhard ${ }^{122}$ at the University of Minnesota and Scott and colleagues ${ }^{123}$ at Vanderbilt University, and this culminated in the Program of Surgical Control of Hyperlipidemias (POSCH) trial $^{124}$. From these studies, as one would expect, there were tremendous improvements in total cholesterol levels that were attributed to the lack of bile-nutrient mixing and thus retarded lipid absorption.

At the time bile diversion was developed, bile acids had not yet been recognized as the metabolic hormones that we know today ${ }^{125,126}$. Thus, more recent studies have revitalized the potential uses for bile diversion as a model to dissect the mechanisms at work following bariatric surgery because of its similarities to other bariatric procedures. Bile diversion, similar to RYGB or BPD, limits bile-nutrient mixing until a more distal point in the intestine. Unlike the RYGB or BPD, though, there is no biliopancreatic limb for these secretions to flow; they are completely diverted by cannula or anastomosis directly to the intestinal segment of interest maintaining unaltered alimentary flow. Coincidentally, it was noted that glucose tolerance was improved even in the absence of weight loss in dogs after bile diversion ${ }^{127}$. Manfredini and colleagues $^{128}$ replicated these observations and described improvements in oral and intravenous glucose tolerance in the absence of any changes in insulin secretion. However, a recent report of bile diversion in lean rats has shown conflicting results on whether insulin secretion is altered, and this requires further study ${ }^{128,129}$.

Regardless of whether insulin secretion is altered, there is improved insulin responsiveness and decreased fasting glucose after bile diversion suggestive of a change in insulin sensitivity in lean rats ${ }^{129}$. Similarly, in a high fat-fed model, Kohli and colleagues ${ }^{130}$ have shown that bile diversion to the jejunum produces weight loss compared with sham/control rats. These beneficial changes are recapitulated with oral bile acid administration and appear to be mediated by alleviating endoplasmic reticulum stress. Moreover, bile diversion in rats was associated with increased number and length of villi, similar to procedures like RYGB, BPD, and ileal interposition $^{130,131}$. Each of the bile diversion models is associated with increased circulating bile acid concentrations, which appear to be necessary for the metabolic effects since administration of bile acid sequestrants (for example, cholestyramine) normalizes plasma bile acid concentrations and abolishes the metabolic improvements. These findings are consistent with our recent studies using a gallbladder to ileum anastomosis in the mouse, which compared it alongside RYGB in a mouse model of diet-induced obesity. Similar to the findings in rats, bile diversion in mice is associated with striking improvements in glucose tolerance, insulin sensitivity, normalization of blood lipids, and complete resolution of hepatic steatosis ${ }^{63}$. These changes are secondary to a degree of malabsorption of dietary lipid in the mice; however, they are also observed with marked increases in total circulating bile acids-specific bile acids that are implicated in metabolic signaling through bile acids receptors (that is, TGR5 and FXR) ${ }^{125,132}$. 


\section{Role of bile acids and the gut microbiome}

The contributions of bile acids in the metabolic effects following bariatric surgery are at the forefront of current investigation. There is considerable evidence that bile acid concentrations are increased following bariatric surgical procedures-both clinical and experimental-and the most robust clinical changes are observed in RYGB and BPD ${ }^{133-138}$. Whether the changes in circulating bile acid concentrations lead to changes in known downstream metabolic effectors like fibroblast growth factor 19 (FGF19, FGF15 in rodents) is still under investigation ${ }^{139}$. The changes in bile acid metabolism and circulating concentrations appear to be dynamic following $\mathrm{RYGB}^{133}$ and this may explain why some investigators observe increases in the metabolically beneficial hormone FGF19 and some do $\operatorname{not}^{133,138,140-142}$. From a mechanistic perspective, the fact that the ileal interposition and bile diversion procedures recapitulate these bile acid elevations is quite intriguing and implies that either absence of bile in the proximal intestine or overabundance in the distal intestine may contribute the metabolic effects observed. The changes in bile acids appear to be mediated in part by increases in bile acid synthesis through increased expression of CYP7A1, the rate-limiting enzyme in bile acid synthesis. However, there are also concurrent changes in bile acid transporter proteins in the liver and the ileum ${ }^{63}$ that would also be expected to increase the circulating total bile acid pool. Paradoxically, bile acid synthesis is elevated in the face of increased SHP and decreased FXR expression in the livers of these animals. These changes in SHP and FXR expression are inconsistent with our current understanding of hepatic bile acid synthesis ${ }^{143}$. Regardless of how bile acid concentrations are increased following the ileal interposition and bile diversion procedures, the molecular mechanisms of how the increased abundance of bile acids may alter glucose homeostasis is currently unknown. Evidence suggests that these effects are mediated via FXR or TGR5 signaling (or both) in the beta-cell or in the enterocytes themselves (or in both) ${ }^{125,144,145}$, but further studies need to focus on clarifying these mechanisms and their physiologic importance. These bile acid-mediated effects on glucose and lipid metabolism have therapeutic implications on diabetes irrespectively of changes on body weight and are a focus of current investigation.

Perhaps one of the most intriguing observations of this century thus far has been that fecal transfer of gut microbiota from obese donors causes weight gain in lean recipients ${ }^{146}$. Similarly, the opposite effect can be demonstrated in obese mice with stool from RYGB mouse donors, which demonstrates the transferability of at least some of the metabolic benefits of gastric bypass ${ }^{147}$. There has been significant evidence that the gut microbiota is altered following bariatric surgery, although the mechanisms of these changes and the potential contribution they make in the metabolic benefits post-operatively are unknown. Changes in the microbiota have been examined in mouse models of sleeve gastrectomy ${ }^{48}$ as well as biliary diversion ${ }^{63}$, and these procedures show what appear to be beneficial changes. Interestingly, le Roux and colleagues ${ }^{148}$ have recently shown that the gut microbiota alter the pattern of adipose tissue deposition. The interaction between the gut microbiota and bile acid metabolism is complex, and particular bile acids are antibacterial and likely affect the gut microbiota. In contrast, the gut microbiota are the major source of bile acid diversity, chemically transforming endogenously produced bile acids to a number of different chemical species that likely have varying potencies at bile acid receptors. At this time, it is not clear whether these changes in microbiota are a cause or an effect of the metabolic improvements and weight loss observed following bariatric surgery, but the potential for altering the microbiome as a treatment for obesity or diabetes (or both) continues to emerge $\mathrm{e}^{149}$.

\section{Summary and future directions}

From a clinical perspective, prospective clinical trials are needed to directly compare not only durability of weight loss but also resolution of other obesity comorbidities (for example, diabetes, insulin resistance, and hyperlipidemias) after VSG and RYGB ${ }^{150}$. Scientifically, while much progress has been made regarding the weight loss-independent metabolic effects of bariatric surgery, the complexity of the system continues to provide challenges. The field is progressing from a "GLP-1-centric view" of bariatric surgery to encompass the importance of early benefits of caloric restriction and non-traditional regulators of metabolism. The changes in bile acid metabolism with bariatric surgery will continue to drive the study of these procedures and the mechanisms in animal models - especially as the bile acid field continues to advance our understanding of these potent metabolic regulators. Lastly, the interaction of the bile acid milieu and the gut microbiome cannot be ignored. The gut microbiome field continues to grow and become more intervention-driven, as opposed to descriptive, and will continue to help identify the changes underlying the metabolic benefits of bariatric and metabolic surgery. These continue to be exciting times for metabolic and bariatric surgical research, and future studies examining the contributions of bile acids and microbiota both clinically and experimentally may lead to more effective treatments, and perhaps new interventional procedures for obesity and diabetes.

\section{Competing interests}

The authors declare that they have no competing interests.

\section{Grant information}

The National Institute of Diabetes and Digestive and Kidney Diseases supported this work through the following grants: F32DK103474 (VLA), R01DK091748, R01DK070860, R01 DK105847, R01DK100431, R24DK093421-01A1, and DK058404 (Vanderbilt Digestive Disease Research Center), DK20593 (Vanderbilt Diabetes Research and Training Center), and 1UL1RR024975 (Vanderbilt Clinical and Translational Science Award).

The funders had no role in study design, data collection and analysis, decision to publish, or preparation of the manuscript.

\section{Acknowledgments}

The authors would like to thank Henry Buchwald (University of Minnesota) for his historical insight into the ileal bypass and early bile diversion procedures. 
1. Blackburn G: Effect of degree of weight loss on health benefits. Obes Res. 1995; 3(Suppl 2): 211s-216s.

PubMed Abstract | Publisher Full Text

2. Look AHEAD Research Group: Eight-year weight losses with an intensive lifestyle intervention: the look AHEAD study. Obesity (Silver Spring). 2014; 22(1): 5-13

PubMed Abstract | Publisher Full Text | Free Full Text

3. Wing RR, Lang W, Wadden TA, et al:: Benefits of modest weight loss in improving cardiovascular risk factors in overweight and obese individuals with type 2 diabetes. Diabetes Care. 2011; 34(7): 1481-6.

PubMed Abstract | Publisher Full Text | Free Full Text

4. Schauer PR, Bhatt DL, Kirwan JP, et al.: Bariatric surgery versus intensive medical therapy for diabetes--3-year outcomes. N Engl J Med. 2014; 370(21): 2002-13.

PubMed Abstract | Publisher Full Text

5. F Schauer PR, Kashyap SR, Wolski K, et al:: Bariatric surgery versus intensive medical therapy in obese patients with diabetes. N Engl J Med. 2012; 366(17): 1567-76.

PubMed Abstract | Publisher Full Text | Free Full Text | F1000 Recommendation

6. Courcoulas AP, Goodpaster BH, Eagleton JK, et al:: Surgical vs medical treatments for type 2 diabetes mellitus: a randomized clinical trial. JAMA Surg. 2014; 149(7): 707-15

PubMed Abstract | Publisher Full Text | Free Full Text

7. Courcoulas AP, Christian NJ, O'Rourke RW, et al:: Preoperative factors and 3-year weight change in the Longitudinal Assessment of Bariatric Surgery (LABS) consortium. Surg Obes Relat Dis. 2015; 11(5): 1109-18. PubMed Abstract | Publisher Full Text | Free Full Text

8. F Pories WJ, Swanson MS, MacDonald KG, et al.: Who would have thought it? An operation proves to be the most effective therapy for adult-onset diabetes mellitus. Ann Surg. 1995; 222(3): 339-50; discussion 350-2.

PubMed Abstract | Publisher Full Text | Free Full Text | F1000 Recommendation

9. Wickremesekera K, Miller G, Naotunne TD, et al.: Loss of insulin resistance after Roux-en-Y gastric bypass surgery: a time course study. Obes Surg. 2005; 15(4): 474-81.

PubMed Abstract | Publisher Full Text

10. F Jørgensen NB, Jacobsen SH, Dirksen C, et al:: Acute and long-term effects of Roux-en-Y gastric bypass on glucose metabolism in subjects with Type 2 diabetes and normal glucose tolerance. Am J Physiol Endocrinol Metab. 2012; 303(1): E122-31.

PubMed Abstract | Publisher Full Text | F1000 Recommendation

11. Ackerman NB: Observations on the improvements in carbohydrate metabolism in diabetic and other morbidly obese patients after jejunoileal bypass. Surg Gynecol Obstet. 1981; 152(5): 581-6. PubMed Abstract

12. $\mathrm{F}$ Buchwald $\mathrm{H}$, Avidor $\mathrm{Y}$, Braunwald $\mathrm{E}$, et al:: Bariatric surgery: a systematic review and meta-analysis. JAMA. 2004; 292(14): 1724-37. PubMed Abstract | Publisher Full Text | F1000 Recommendation

13. F Sjöström L, Lindroos AK, Peltonen M, et al.: Lifestyle, diabetes, and cardiovascular risk factors 10 years after bariatric surgery. N Engl J Med. 2004 351(26): 2683-93.

PubMed Abstract | Publisher Full Text | F1000 Recommendation

14. Sugerman HJ, Wolfe LG, Sica DA, et al.: Diabetes and hypertension in severe obesity and effects of gastric bypass-induced weight loss. Ann Surg. 2003; 237(6): 751-6; discussion 757-8.

PubMed Abstract | Publisher Full Text | Free Full Text

15. Scopinaro N, Papadia F, Marinari G, et al.: Long-term control of type 2 diabetes mellitus and the other major components of the metabolic syndrome after biliopancreatic diversion in patients with $\mathrm{BMI}<35 \mathrm{~kg} / \mathrm{m}^{2}$. Obes Surg. 2007; 17(2): 185-92.

PubMed Abstract | Publisher Full Text

16. Fried M, Ribaric G, Buchwald JN, et al.: Metabolic surgery for the treatment of type 2 diabetes in patients with $\mathrm{BMI}<35 \mathrm{~kg} / \mathrm{m}^{2}$ : an integrative review of early studies. Obes Surg. 2010; 20(6): 776-90.

PubMed Abstract | Publisher Full Text

17. Scopinaro N, Adami GF, Papadia FS, et al:: Effects of biliopanceratic diversion on type 2 diabetes in patients with BMI 25 to 35. Ann Surg. 2011; 253(4): 699-703. PubMed Abstract | Publisher Full Text

18. Scopinaro N, Adami GF, Papadia FS, et al:: The effects of biliopancreatic diversion on type 2 diabetes mellitus in patients with mild obesity (BMI $30-35 \mathrm{~kg} / \mathrm{m}^{2}$ ) and simple overweight (BMI $\left.25-30 \mathrm{~kg} / \mathrm{m}^{2}\right)$ : a prospective controlled study. Obes simple overweight (BMI $25-$ Surg. 2011; 21(7): 880-8.
PubMed Abstract | Publisher Full Text

19. F Scopinaro N, Adami GF, Papadia FS, et al.: Effects of gastric bypass on type 2 diabetes in patients with BMI 30 to 35 . Obes Surg. 2014; 24(7): 1036-43. PubMed Abstract | Publisher Full Text | F1000 Recommendation

20. Adams TD, Davidson LE, Litwin SE, et al.: Health benefits of gastric bypass surgery after 6 years. JAMA. 2012; 308(11): 1122-31. PubMed Abstract | Publisher Full Text | Free Full Text
21. Adams TD, Gress RE, Smith SC, et al.: Long-term mortality after gastric bypass surgery. N Engl J Med. 2007; 357(8): 753-61.

PubMed Abstract | Publisher Full Text

22. Borisenko O, Adam D, Funch-Jensen P, et al.: Bariatric Surgery can Lead to Net Cost Savings to Health Care Systems: Results from a Comprehensive European Decision Analytic Model. Obes Surg. 2015; 25(9): 1559-68. PubMed Abstract | Publisher Full Text | Free Full Text

23. Dimick JB: Does Bariatric Surgery Reduce Health Care Costs?: Weighing the Evidence. JAMA Surg. 2015; 150(8): 795. PubMed Abstract | Publisher Full Text

24. $\mathrm{F}$ Lewis $\mathrm{KH}$, Zhang $\mathrm{F}$, Arterburn DE, et al:: Comparing Medical Costs and Use After Laparoscopic Adjustable Gastric Banding and Roux-en-Y Gastric Bypass. JAMA Surg. 2015; 150(8): 787-94. PubMed Abstract | Publisher Full Text | Free Full Text | F1000 Recommendation

25. F Stefater MA, Wilson-Pérez HE, Chambers AP, et al:: All bariatric surgeries are not created equal: insights from mechanistic comparisons. Endocr Rev. 2012; 33(4): 595-622.

PubMed Abstract | Publisher Full Text | Free Full Text | F1000 Recommendation

26. F Angrisani L, Santonicola A, lovino P, et al:: Bariatric Surgery Worldwide 2013. Obes Surg. 2015; 25(10): 1822-32.

PubMed Abstract | Publisher Full Text | F1000 Recommendation

27. Yin DP, Gao Q, Ma LL, et al:: Assessment of different bariatric surgeries in the treatment of obesity and insulin resistance in mice. Ann Surg. 2011; 254(1): 73-82. PubMed Abstract | Publisher Full Text | Free Full Text

28. Yin DP, Boyd KL, Williams PE, et al.: Mouse Models of Bariatric Surgery. Curr Protoc Mouse Biol. 2012; 2012: pii: mo120087.

PubMed Abstract | Publisher Full Text | Free Full Text

29. Masuda T, Ohta M, Hirashita T, et al:: A comparative study of gastric banding and sleeve gastrectomy in an obese diabetic rat model. Obes Surg. 2011; 21(11): 1774-80.

PubMed Abstract | Publisher Full Text

30. Kawasaki $\mathrm{T}$, Ohta M, Kawano $\mathrm{Y}$, et al:: Effects of sleeve gastrectomy and gastric banding on the hypothalamic feeding center in an obese rat model. Surg Today. 2015; 45(12): 1560-6.

PubMed Abstract | Publisher Full Tex

31. Hirashita $T$, Ohta $M$, Endo $Y$, et al: Effects of visceral fat resection and gastric banding in an obese diabetic rat model. Surgery. 2012; 151(1): 6-12. PubMed Abstract | Publisher Full Text

32. Kohli R, Bradley D, Setchell KD, et al:: Weight loss induced by Roux-en-Y gastric bypass but not laparoscopic adjustable gastric banding increases circulating bile acids. J Clin Endocrinol Metab. 2013; 98(4): E708-12. PubMed Abstract | Publisher Full Text | Free Full Text

33. Usinger L, Hansen KB, Kristiansen VB, et al:: Gastric emptying of orally administered glucose solutions and incretin hormone responses are unaffected by laparoscopic adjustable gastric banding. Obes Surg. 2011; 21(5): 625-32. PubMed Abstract | Publisher Full Text

34. F Dixon JB, O'Brien PE, Playfair J, et al.: Adjustable gastric banding and conventional therapy for type 2 diabetes: a randomized controlled trial. JAMA. 2008; 299(3): 316-23.

PubMed Abstract | Publisher Full Text | F1000 Recommendation

35. Frühbeck G, Rotellar F, Hernández-Lizoain JL, et al.: Fasting plasma ghrelin concentrations 6 months after gastric bypass are not determined by weight loss or changes in insulinemia. Obes Surg. 2004; 14(9): 1208-15. PubMed Abstract | Publisher Full Text

36. Genco A, López-Nava G, Wahlen C, et al.: Multi-centre European experience with intragastric balloon in overweight populations: 13 years of experience. Obes Surg. 2013; 23(4): 515-21. PubMed Abstract | Publisher Full Text

37. F Lopez-Nava G, Bautista-Castaño I, Jimenez-Baños A, et al:: Dual Intragastric Balloon: Single Ambulatory Center Spanish Experience with 60 Patients in Endoscopic Weight Loss Management. Obes Surg. 2015; 25(12): 2263-7. PubMed Abstract | Publisher Full Text | F1000 Recommendation

38. F Ponce J, Woodman G, Swain J, et al.: The REDUCE pivotal trial: a prospective, randomized controlled pivotal trial of a dual intragastric balloon for the treatment of obesity. Surg Obes Relat Dis. 2015; 11(4): 874-81. PubMed Abstract | Publisher Full Text | F1000 Recommendation

39. Grayson BE, Schneider KM, Woods SC, et al:: Improved rodent maternal metabolism but reduced intrauterine growth after vertical sleeve gastrectomy. Sci Transl Med. 2013; 5(199): 199ra112. PubMed Abstract | Publisher Full Text | Free Full Text

40. National Research Council (US) Subcommittee on Laboratory Animal Nutrition: Nutrient Requirements of Laboratory Animals: Fourth Revised Edition, 1995. National Academies, 1995; 1.

PubMed Abstract | Publisher Full Text

41. Choi E, Roland JT, Barlow BJ, et al:: Cell lineage distribution atlas of the human stomach reveals heterogeneous gland populations in the gastric antrum. Gut. 2014; 63(11): 1711-20.

PubMed Abstract | Publisher Full Text | Free Full Text 
42. Karamanakos SN, Vagenas K, Kalfarentzos F, et al.: Weight loss, appetite suppression, and changes in fasting and postprandial ghrelin and peptide-YY levels after Roux-en-Y gastric bypass and sleeve gastrectomy: a prospective, double blind study. Ann Surg. 2008; 247(3): 401-7.

PubMed Abstract | Publisher Full Text

43. Peterli R, Steinert RE, Woelnerhanssen B, et al.: Metabolic and hormonal changes after laparoscopic Roux-en- $Y$ gastric bypass and sleeve gastrectomy: a randomized, prospective trial. Obes Surg. 2012; 22(5): 740-8. PubMed Abstract | Publisher Full Text | Free Full Text

44. Papamargaritis D, Le Roux CW, Sioka E, et al:: Changes in gut hormone profile and glucose homeostasis after laparoscopic sleeve gastrectomy. Surg Obes Relat Dis. 2013; 9(2): 192-201.

PubMed Abstract | Publisher Full Text

45. Mallipedhi A, Prior SL, Barry JD, et al:: Temporal changes in glucose homeostasis and incretin hormone response at 1 and 6 months afte laparoscopic sleeve gastrectomy. Surg Obes Relat Dis. 2014; 10(5): 860-9. PubMed Abstract | Publisher Full Text

46. Chambers AP, Kirchner H, Wilson-Perez HE, et al:: The effects of vertical sleeve gastrectomy in rodents are ghrelin independent. Gastroenterology. 2013; 144(1): 50-52.e5.

PubMed Abstract | Publisher Full Text | Free Full Text

47. Wilson-Pérez HE, Chambers AP, Ryan KK, et al.: Vertical sleeve gastrectomy is effective in two genetic mouse models of glucagon-like Peptide 1 receptor deficiency. Diabetes. 2013; 62(7): 2380-5

PubMed Abstract | Publisher Full Text | Free Full Text

48. F Ryan KK, Tremaroli V, Clemmensen C, et al:: FXR is a molecular target for the effects of vertical sleeve gastrectomy. Nature. 2014; 509(7499): 183-8. PubMed Abstract | Publisher Full Text | Free Full Text | F1000 Recommendation

49. F Myronovych A, Kirby M, Ryan KK, et al:: Vertical sleeve gastrectomy reduces hepatic steatosis while increasing serum bile acids in a weight-loss-independent manner. Obesity (Silver Spring). 2014; 22(2): 390-400.

PubMed Abstract | Publisher Full Text | Free Full Text | F1000 Recommendation

50. F Belgaumkar AP, Vincent RP, Carswell KA, et al.: Changes in Bile Acid Profile After Laparoscopic Sleeve Gastrectomy are Associated with Improvements in Metabolic Profile and Fatty Liver Disease. Obes Surg. 2016. 26(6): 1195-202. PubMed Abstract | Publisher Full Text | F1000 Recommendation

51. Wilson-Pérez HE, Chambers AP, Sandoval DA, et al:: The effect of vertical sleeve gastrectomy on food choice in rats. Int J Obes (Lond). 2013; 37(2): 288-95. PubMed Abstract | Publisher Full Text | Free Full Text

52. le Roux CW, Bueter M, Theis N, et al.: Gastric bypass reduces fat intake and preference. Am J Physiol Regul Integr Comp Physiol. 2011; 301(4): R1057-66. PubMed Abstract | Publisher Full Text | Free Full Text

53. Chambers AP, Wilson-Perez HE, McGrath S, et al:: Effect of vertical sleeve gastrectomy on food selection and satiation in rats. Am J Physiol Endocrinol Metab. 2012; 303(8): E1076-84.

PubMed Abstract | Publisher Full Text | Free Full Text

54. Stefater MA, Sandoval DA, Chambers AP, et al:: Sleeve gastrectomy in rats improves postprandial lipid clearance by reducing intestinal triglyceride secretion. Gastroenterology. 2011; 141(3): 939-949.e1-4. PubMed Abstract | Publisher Full Text | Free Full Text

55. Hammer HF: Medical complications of bariatric surgery: focus on malabsorption and dumping syndrome. Dig Dis. 2012; 30(2): 182-6. PubMed Abstract | Publisher Full Text

56. Isom KA, Andromalos L, Ariagno $\mathrm{M}$, et al:: Nutrition and metabolic support recommendations for the bariatric patient. Nutr Clin Pract. 2014; 29(6): 718-39. PubMed Abstract | Publisher Full Text

57. Topart $P$, Becouarn $G$, Sallé $A$, et al:: Biliopancreatic diversion requires multiple vitamin and micronutrient adjustments within 2 years of surgery. Surg Obes Relat Dis. 2014; 10(5): 936-41. PubMed Abstract | Publisher Full Tex

58. $\mathrm{F}$ Risstad H, Søvik TT, Engström M, et al.: Five-year outcomes after laparoscopic gastric bypass and laparoscopic duodenal switch in patients with body mass index of 50 to 60: a randomized clinical trial. JAMA Surg. 2015 150(4): 352-61.

PubMed Abstract | Publisher Full Text | F1000 Recommendation

59. $\mathrm{F}$ Marceau $\mathrm{P}$, Biron S, Marceau S, et al.: Biliopancreatic diversion-duodenal switch: independent contributions of sleeve resection and duodenal exclusion. Obes Surg. 2014; 24(11): 1843-9.

PubMed Abstract | Publisher Full Text | F1000 Recommendation

60. Meirelles K, Ahmed T, Culnan DM, et al:: Mechanisms of glucose homeostasis after Roux-en- $Y$ gastric bypass surgery in the obese, insulin-resistant Zucker rat. Ann Surg. 2009; 249(2): 277-85.

PubMed Abstract | Publisher Full Text | Free Full Text

61. F Mingrone G, Panunzi S, De Gaetano A, et al.: Bariatric surgery versus conventional medical therapy for type 2 diabetes. N Engl J Med. 2012; 366(17): 1577-85.

PubMed Abstract | Publisher Full Text | F1000 Recommendation

62. Astiarraga B, Gastaldelli A, Muscelli E, et al.: Biliopancreatic diversion in nonobese patients with type 2 diabetes: impact and mechanisms. J Clin Endocrinol Metab. 2013; 98(7): 2765-73. PubMed Abstract | Publisher Full Text
63. F Flynn CR, Albaugh VL, Cai S, et al.: Bile diversion to the distal smal intestine has comparable metabolic benefits to bariatric surgery. Nat Commun. 2015; 6: 7715

PubMed Abstract | Publisher Full Text | Free Full Text | F1000 Recommendation

64. F Li W, Baraboi ED, Cluny NL, et al:: Malabsorption plays a major role in the effects of the biliopancreatic diversion with duodenal switch on energy metabolism in rats. Surg Obes Relat Dis. 2015; 11(2): 356-66.

PubMed Abstract | Publisher Full Text | F1000 Recommendation

65. Scopinaro N, Adami GF, Marinari GM, et al.: Biliopancreatic diversion. World J Surg. 1998; 22(9): 936-46.

PubMed Abstract | Publisher Full Tex

66. F Carswell KA, Vincent RP, Belgaumkar AP, et al:: The effect of bariatric surgery on intestinal absorption and transit time. Obes Surg. 2014; 24(5): 796-805. PubMed Abstract | Publisher Full Text | F1000 Recommendation

67. Odstrcil EA, Martinez JG, Santa Ana CA, et al:: The contribution of malabsorption to the reduction in net energy absorption after long-limb Roux-en-Y gastric bypass. Am J Clin Nutr. 2010; 92(4): 704-13.

PubMed Abstract | Publisher Full Text

68. Wang G, Agenor K, Pizot J, et al:: Accelerated gastric emptying but no carbohydrate malabsorption 1 year after gastric bypass surgery (GBP). Obes Surg. 2012; 22(8): 1263-7.

PubMed Abstract | Publisher Full Text | Free Full Text

69. Scopinaro N, Marinari GM, Pretolesi F, et al.: Energy and nitrogen absorption after biliopancreatic diversion. Obes Surg. 2000; 10(5): 436-41. PubMed Abstract | Publisher Full Text

70. Stock-Damgé C, Aprahamian M, Raul F, et al.: Small-intestinal and colonic changes after biliopancreatic bypass for morbid obesity. Scand J Gastroenterol. 1986; 21(9): 1115-23.

PubMed Abstract | Publisher Full Text

71. Scopinaro N, Gianetta E, Adami GF, et al:: Biliopancreatic diversion for obesity at eighteen years. Surgery. 1996; 119(3): 261-8.

PubMed Abstract | Publisher Full Text

72. Pacheco D, de Luis DA, Romero A, et al:: The effects of duodenal-jejunal exclusion on hormonal regulation of glucose metabolism in Goto-Kakizaki rats. Am J Surg. 2007; 194(2): 221-4. PubMed Abstract | Publisher Full Text

73. Rubino F, Marescaux J: Effect of duodenal-jejunal exclusion in a non-obese animal model of type 2 diabetes: a new perspective for an old disease. Ann Surg. 2004; 239(1): 1-11.

PubMed Abstract | Publisher Full Text | Free Full Text

74. Hansen EN, Tamboli RA, Isbell JM, et al:: Role of the foregut in the early improvement in glucose tolerance and insulin sensitivity following Roux-en- $Y$ gastric bypass surgery. Am J Physiol Gastrointest Liver Physiol. 2011; 300(5): G795-802.

PubMed Abstract | Publisher Full Text | Free Full Text

75. Pournaras DJ, Aasheim ET, Bueter M, et al.: Effect of bypassing the proximal gut on gut hormones involved with glycemic control and weight loss. Surg Obes Relat Dis. 2012; 8(4): 371-4.

PubMed Abstract | Publisher Full Text

76. F Habegger KM, Al-Massadi O, Heppner KM, et al:: Duodenal nutrient exclusion improves metabolic syndrome and stimulates villus hyperplasia. Gut. 2014; 63(8): 1238-46.

PubMed Abstract | Publisher Full Text | Free Full Text | F1000 Recommendation

77. Kindel TL, Martins PJ, Yoder SM, et al:: Bypassing the duodenum does not improve insulin resistance associated with diet-induced obesity in rodents. Obesity (Silver Spring). 2011; 19(2): 380-7.

PubMed Abstract | Publisher Full Text | Free Full Text

78. Kindel TL, Yoder SM, Seeley RJ, et al.: Duodenal-jejunal exclusion improves glucose tolerance in the diabetic, Goto-Kakizaki rat by a GLP-1 receptormediated mechanism. J Gastrointest Surg. 2009; 13(10): 1762-72. PubMed Abstract | Publisher Full Text

79. Rubino F, Forgione A, Cummings DE, et al.: The mechanism of diabetes contro after gastrointestinal bypass surgery reveals a role of the proximal small intestine in the pathophysiology of type 2 diabetes. Ann Surg. 2006; 244(5): $741-9$.

PubMed Abstract | Publisher Full Text | Free Full Text

80. $\mathrm{F}$ Vetter $\mathrm{ML}$, Wadden $\mathrm{TA}$, Teff $\mathrm{KL}$, et al:: GLP-1 plays a limited role in improved glycemia shortly after Roux-en-Y gastric bypass: a comparison with intensive lifestyle modification. Diabetes. 2015; 64(2): 434-46.

PubMed Abstract | Publisher Full Text | Free Full Text | F1000 Recommendation

81. Spak E, Björklund $P$, Helander HF, et al:: Changes in the mucosa of the Roux-limb after gastric bypass surgery. Histopathology. 2010; 57(5): 680-8.

PubMed Abstract | Publisher Full Text

82. F Saeidi N, Meoli L, Nestoridi E, et al:: Reprogramming of intestinal glucose metabolism and glycemic control in rats after gastric bypass. Science. 2013; 341(6144): 406-10.

PubMed Abstract | Publisher Full Text | Free Full Text | F1000 Recommendation

83. Borg CM, le Roux CW, Ghatei MA, et al:: Biliopancreatic diversion in rats is associated with intestinal hypertrophy and with increased GLP-1, GLP-2 and PYY levels. Obes Surg. 2007; 17(9): 1193-8.

PubMed Abstract | Publisher Full Text 
84. F Rhee NA, Wahlgren CD, Pedersen J, et al.: Effect of Roux-en-Y gastric bypass on the distribution and hormone expression of small-intestinal enteroendocrine cells in obese patients with type 2 diabetes. Diabetologia. 2015; 58(10): 2254-8

PubMed Abstract | Publisher Full Text | F1000 Recommendation

85. le Roux CW, Borg C, Wallis K, et al.: Gut hypertrophy after gastric bypass is associated with increased glucagon-like peptide 2 and intestinal crypt cell proliferation. Ann Surg. 2010; 252(1): 50-6.

PubMed Abstract | Publisher Full Text

86. F Pepino MY, Bradley D, Eagon JC, et al.: Changes in taste perception and eating behavior after bariatric surgery-induced weight loss in women. Obesity (Silver Spring). 2014; 22(5): E13-20.

PubMed Abstract | Publisher Full Text | Free Full Text | F1000 Recommendation

87. F Pepino MY, Stein RI, Eagon JC, et al.: Bariatric surgery-induced weight loss causes remission of food addiction in extreme obesity. Obesity (Silver Spring). 2014; 22(8): 1792-8.

PubMed Abstract | Publisher Full Text | Free Full Text | F1000 Recommendation

88. Hajnal A, Kovacs $P$, Ahmed $T$, et al.: Gastric bypass surgery alters behavioral and neural taste functions for sweet taste in obese rats. Am J Physiol Gastrointest Liver Physiol. 2010; 299(4): G967-79.

PubMed Abstract | Publisher Full Text | Free Full Text

89. Thanos PK, Subrize M, Delis F, et al:: Gastric bypass increases ethanol and water consumption in diet-induced obese rats. Obes Surg. 2012; 22(12): 1884-92. PubMed Abstract | Publisher Full Text | Free Full Text

90. Dunn JP, Cowan RL, Volkow ND, et al.: Decreased dopamine type 2 receptor availability after bariatric surgery: preliminary findings. Brain Res. 2010; 1350 123-30.

PubMed Abstract | Publisher Full Text | Free Full Text

91. F Thanos PK, Michaelides M, Subrize M, et al.: Roux-en-Y Gastric Bypass Alters Brain Activity in Regions that Underlie Reward and Taste Perception. PLoS One. 2015; 10(6): e0125570.

PubMed Abstract | Publisher Full Text | Free Full Text | F1000 Recommendation

92. F Pal A, Rhoads DB, Tavakkoli A: Foregut exclusion disrupts intestinal glucose sensing and alters portal nutrient and hormonal milieu. Diabetes. 2015; 64(6): 1941-50.

PubMed Abstract | Publisher Full Text | Free Full Text | F1000 Recommendation

93. Shin $\mathrm{AC}$, Zheng $\mathrm{H}$, Berthoud HR: Vagal innervation of the hepatic portal vein and liver is not necessary for Roux-en- $Y$ gastric bypass surgery-induced hypophagia, weight loss, and hypermetabolism. Ann Surg. 2012; 255(2): 294-301. PubMed Abstract | Publisher Full Text | Free Full Text

94. F Bhutta HY, Rajpal N, White W, et al.: Effect of Roux-en-Y gastric bypass surgery on bile acid metabolism in normal and obese diabetic rats. PLOS One. 2015; 10(3): e0122273.

PubMed Abstract | Publisher Full Text | Free Full Text | F1000 Recommendation

95. Isbell JM, Tamboli RA, Hansen EN, et al:: The importance of caloric restriction in the early improvements in insulin sensitivity after Roux-en- $Y$ gastric bypass surgery. Diabetes Care. 2010; 33(7): 1438-42.

PubMed Abstract | Publisher Full Text | Free Full Text

96. Jackness C, Karmally W, Febres G, et al.: Very low-calorie diet mimics the early beneficial effect of Roux-en-Y gastric bypass on insulin sensitivity and $\beta$-cell Function in type 2 diabetic patients. Diabetes. 2013; 62(9): 3027-32. PubMed Abstract | Publisher Full Text | Free Full Text

97. Oliván B, Teixeira J, Bose M, et al.: Effect of weight loss by diet or gastric bypass surgery on peptide YY3-36 levels. Ann Surg. 2009; 249(6): 948-53. PubMed Abstract | Publisher Full Text | Free Full Text

98. Dunn JP, Abumrad NN, Breitman I, et al.: Hepatic and peripheral insulin sensitivity and diabetes remission at 1 month after Roux-en-Y gastric bypass surgery in patients randomized to omentectomy. Diabetes Care. 2012; 35(1): $137-42$.

PubMed Abstract | Publisher Full Text | Free Full Text

99. Bojsen-Møller KN, Dirksen C, Jørgensen NB, et al:: Early enhancements of hepatic and later of peripheral insulin sensitivity combined with increased postprandial insulin secretion contribute to improved glycemic control after Roux-en-Y gastric bypass. Diabetes. 2014; 63(5): 1725-37. PubMed Abstract | Publisher Full Text

100. Tamboli RA, Breitman I, Marks-Shulman PA, et al.: Early weight regain after gastric bypass does not affect insulin sensitivity but is associated with elevated ghrelin. Obesity (Silver Spring). 2014; 22(7): 1617-22. PubMed Abstract | Publisher Full Text | Free Full Text

101. Campos GM, Rabl C, Peeva S, et al.: Improvement in peripheral glucose uptake after gastric bypass surgery is observed only after substantial weight loss has occurred and correlates with the magnitude of weight lost. J Gastrointest Surg. 2010; 14(1): 15-23.

PubMed Abstract | Publisher Full Text | Free Full Text

102. Nestoridi $\mathrm{E}$, Kvas S, Kucharczyk J, et al.: Resting energy expenditure and energetic cost of feeding are augmented after Roux-en-Y gastric bypass in obese mice. Endocrinology. 2012; 153(5): 2234-44. PubMed Abstract | Publisher Full Text

103. Stylopoulos N, Hoppin AG, Kaplan LM: Roux-en-Y gastric bypass enhances energy expenditure and extends lifespan in diet-induced obese rats. Obesity (Silver Spring). 2009; 17(10): 1839-47.

PubMed Abstract | Publisher Full Text | Free Full Text
104. Shin AC, Zheng $\mathrm{H}$, Townsend $\mathrm{RL}$, et al.: Longitudinal assessment of food intake, fecal energy loss, and energy expenditure after Roux-en-Y gastric bypass surgery in high-fat-fed obese rats. Obes Surg. 2013; 23(4): 531-40. PubMed Abstract | Publisher Full Text | Free Full Text

105. Kaiyala KJ: Mathematical model for the contribution of individual organs to non-zero $y$-intercepts in single and multi-compartment linear models of wholebody energy expenditure. PLoS One. 2014; 9(7): e103301. PubMed Abstract | Publisher Full Text | Free Full Text

106. Tschöp MH, Speakman JR, Arch JR, et al.: A guide to analysis of mouse energy metabolism. Nat Methods. 2011; 9(1): 57-63. PubMed Abstract | Publisher Full Text | Free Full Text

107. Butler AA, Kozak LP: A recurring problem with the analysis of energy expenditure in genetic models expressing lean and obese phenotypes. Diabetes. 2010; 59(2): 323-9. PubMed Abstract | Publisher Full Text | Free Full Text

108. F Schmidt JB, Pedersen SD, Gregersen NT, et al:: Effects of RYGB on energy expenditure, appetite and glycaemic control: a randomized controlled clinical trial. Int J Obes (Lond). 2016; 40(2): 281-90. PubMed Abstract | Publisher Full Text | F1000 Recommendation

109. Tamboli RA, Hossain HA, Marks PA, et al.: Body composition and energy metabolism following Roux-en-Y gastric bypass surgery. Obesity (Silver Spring). 2010; 18(9): 1718-24.

PubMed Abstract | Publisher Full Text | Free Full Text

110. Knuth ND, Johannsen DL, Tamboli RA, et al:: Metabolic adaptation following massive weight loss is related to the degree of energy imbalance and changes in circulating leptin. Obesity (Silver Spring). 2014; 22(12): 2563-9. PubMed Abstract | Publisher Full Text | Free Full Text

111. Adami GF, Compostano A, Bessarione D, et al:: Resting Energy Expenditure in Long-Term Postobese Subjects after Weight Normalization by Dieting or Biliopancreatic Diversion. Obes Surg. 1993; 3(4): 397-9. PubMed Abstract | Publisher Full Text

112. Koopmans HS, Sclafani A, Fichtner C, et al.: The effects of ileal transposition on food intake and body weight loss in VMH-obese rats. Am J Clin Nutr. 1982; 35(2): 284-93. PubMed Abstrac

113. Culnan DM, Albaugh $\mathrm{V}$, Sun $\mathrm{M}$, et al.: lleal interposition improves glucose tolerance and insulin sensitivity in the obese Zucker rat. Am J Physiol Gastrointest Liver Physiol. 2010; 299(3): G751-60. PubMed Abstract | Publisher Full Text | Free Full Text

114. Cummings BP, Strader AD, Stanhope KL, et al:: lleal interposition surgery improves glucose and lipid metabolism and delays diabetes onset in the UCD-T2DM rat. Gastroenterology. 2010; 138(7): 2437-46, 2446.e1. PubMed Abstract | Publisher Full Text | Free Full Text

115. Strader AD, Vahl TP, Jandacek RJ, et al.: Weight loss through ileal transposition is accompanied by increased ileal hormone secretion and synthesis in rats. Am J Physiol Endocrinol Metab. 2005; 288(2): E447-53.

PubMed Abstract | Publisher Full Text

116. Strader $\mathrm{AD}$, Clausen TR, Goodin SZ, et al:: lleal interposition improves glucose tolerance in low dose streptozotocin-treated diabetic and euglycemic rats. Obes Surg. 2009; 19(1): 96-104.

PubMed Abstract | Publisher Full Text

117. F Ramzy AR, Nausheen S, Chelikani PK: Ileal transposition surgery produces ileal length-dependent changes in food intake, body weight, gut hormones and glucose metabolism in rats. Int $J$ Obes (Lond). 2014; 38(3): 379-87. PubMed Abstract | Publisher Full Text | F1000 Recommendation

118. $\mathrm{F}$ Hansen $\mathrm{CF}$, Vassiliadis $\mathrm{E}$, Vrang $\mathrm{N}$, et al:: The effect of ileal interposition surgery on enteroendocrine cell numbers in the UC Davis type 2 diabetes mellitus rat. Regul Pept. 2014; 189: 31-9.

PubMed Abstract | Publisher Full Text | F1000 Recommendation

119. Tam CS, Berthoud HR, Bueter M, et al: Could the mechanisms of bariatric surgery hold the key for novel therapies? report from a Pennington Scientific Symposium. Obes Rev. 2011; 12(11): 984-94. PubMed Abstract | Publisher Full Text | Free Full Text

120. Keig HE, Belmonte RL Jr, McKain JM, et al:: The effect of bile diversion on induced hypercholesterolemia. Arch Surg. 1968; 96(4): 613-8. PubMled Abstract

121. Morgan CV Jr, Lanier VC, Finch WT, et al.: Protective effects of bile diversion to the distal fourth of small intestine against experimental hypercholesterolemia and atherosclerosis in dogs. Am Surg. 1972; 38(1): 10-2. PubMed Abstract

122. Buchwald H, Gebhard RL: Effect of Intestinal Bypass on Cholesterol Absorption and Blood Levels in the Rabbit. Am J Physiol. 1964; 207: 567-72. PubMed Abstract

123. Scott HW Jr, Stephenson SE Jr, Younger R, et al.: Prevention of experimental atherosclerosis by ileal bypass: 20 per cent cholesterol diet and I-131 induced hypothyroidism in dogs. Ann Surg. 1966; 163(5): 795-807. PubMed Abstract | Free Full Text

124. Buchwald $\mathrm{H}$, Varco RL, Matts JP, et al.: Effect of partial ileal bypass surgery on mortality and morbidity from coronary heart disease in patients with hypercholesterolemia. Report of the Program on the Surgical Control of the Hyperlipidemias (POSCH). N Engl J Med. 1990; 323(14): 946-55. PubMed Abstract | Publisher Full Text

125. F Thomas C, Gioiello A, Noriega L, et al:: TGR5-mediated bile acid sensing 
controls glucose homeostasis. Cell Metab. 2009; 10(3): 167-77. PubMed Abstract | Publisher Full Text | Free Full Text | F1000 Recommendation

126. Lefebvre $\mathrm{P}$, Cariou $\mathrm{B}$, Lien $\mathrm{F}$, et al:: Role of bile acids and bile acid receptors in metabolic regulation. Physiol Rev. 2009; 89(1): 147-91. PubMed Abstract | Publisher Full Text

127. Leriche R, Joung A: Essai sur le traitement chirurgical du diabete par la derivation biliaire: documents experimentaux et cliniques. Annales dEndocrinologie. 1939; 1: 3-10.

128. Manfredini G, Ermini M, Scopsi L, et al:: Internal biliary diversion improves glucose tolerance in the rat. Am J Physiol. 1985; 249(4 Pt 1): G519-27. PubMed Abstract

129. F Goncalves D, Barataud A, De Vadder F, et al.: Bile Routing Modification Reproduces Key Features of Gastric Bypass in Rat. Ann Surg. 2015; 262(6): 1006-15. PubMed Abstract | Publisher Full Text | F1000 Recommendation

130. Kohli $\mathrm{R}$, Setchell $\mathrm{KD}$, Kirby $\mathrm{M}$, et al.: A surgical model in male obese rats uncovers protective effects of bile acids post-bariatric surgery. Endocrinology. 2013; 154(7): 2341-51. PubMed Abstract | Publisher Full Text | Free Full Text

131. Kohli R, Kirby M, Setchell KD, et al.: Intestinal adaptation after ileal interposition surgery increases bile acid recycling and protects against obesity-related comorbidities. Am J Physiol Gastrointest Liver Physiol. 2010; 299(3): G652-60. PubMed Abstract | Publisher Full Text | Free Full Text

132. F Sayin SI, Wahlström A, Felin J, et al:: Gut microbiota regulates bile acid metabolism by reducing the levels of tauro-beta-muricholic acid, a naturally occurring FXR antagonist. Cell Metab. 2013; 17(2): 225-35. PubMed Abstract | Publisher Full Text | F1000 Recommendation

133. Albaugh VL, Flynn CR, Cai S, et al.: Early Increases in Bile Acids Post Roux-en-Y Gastric Bypass Are Driven by Insulin-Sensitizing, Secondary Bile Acids. J Clin Endocrinol Metab. 2015; 100(9): E1225-33. PubMed Abstract | Publisher Full Text | Free Full Text

134. F Steinert RE, Peterli R, Keller S, et al.: Bile acids and gut peptide secretion after bariatric surgery: a 1-year prospective randomized pilot trial. Obesity (Silver Spring). 2013; 21(12): E660-8.

PubMed Abstract | Publisher Full Text | F1000 Recommendation

135. Werling M, Vincent RP, Cross GF, et al.: Enhanced fasting and post-prandial plasma bile acid responses after Roux-en-Y gastric bypass surgery. Scand $J$ Gastroenterol. 2013; 48(11): 1257-64. PubMed Abstract | Publisher Full Tex

136. F Patti ME, Houten SM, Bianco AC, et al.: Serum bile acids are higher in humans with prior gastric bypass: potential contribution to improved glucose and lipid metabolism. Obesity (Silver Spring). 2009; 17(9): 1671-7. PubMed Abstract | Publisher Full Text | Free Full Text | F1000 Recommendation

137. F Dutia R, Embrey M, O'Brien S, et al.: Temporal changes in bile acid levels and $12 \alpha$-hydroxylation after Roux-en- $Y$ gastric bypass surgery in type 2 diabetes. Int J Obes (Lond). 2015; 39(5): 806-13. PubMed Abstract | Publisher Full Text | Free Full Text | F1000 Recommendation

138. Ferrannini E, Camastra S, Astiarraga B, et al.: Increased Bile Acid Synthesis and Deconjugation After Biliopancreatic Diversion. Diabetes. 2015; 64(10): 3377-85. PubMed Abstract | Publisher Full Text | Free Full Text
139. F Ryan KK, Kohli R, Gutierrez-Aguilar R, et al:: Fibroblast growth factor-19 action in the brain reduces food intake and body weight and improves glucose tolerance in male rats. Endocrinology. 2013; 154(1): 9-15.

PubMed Abstract | Publisher Full Text | Free Full Text | F1000 Recommendation

140. Pournaras DJ, Glicksman C, Vincent RP, et al.: The role of bile after Roux-en-Y gastric bypass in promoting weight loss and improving glycaemic control. Endocrinology. 2012; 153(8): 3613-9.

PubMed Abstract | Publisher Full Text | Free Full Text

141. F Gerhard GS, Styer AM, Wood GC, et al:: A role for fibroblast growth factor 19 and bile acids in diabetes remission after Roux-en-Y gastric bypass. Diabetes Care. 2013; 36(7): 1859-64.

PubMed Abstract | Publisher Full Text | Free Full Text | F1000 Recommendation

142. F Jørgensen NB, Dirksen C, Bojsen-Møller KN, et al.: Improvements in glucose metabolism early after gastric bypass surgery are not explained by increases in total bile acids and fibroblast growth factor 19 concentrations. J Clin Endocrinol Metab. 2015; 100(3): E396-406.

PubMed Abstract | Publisher Full Text | F1000 Recommendation

143. F Li S, Hsu DD, Li B, et al:: Cytoplasmic tyrosine phosphatase Shp2 coordinates hepatic regulation of bile acid and FGF15/19 signaling to repress bile acid synthesis. Cell Metab. 2014; 20(2): 320-32.

PubMed Abstract | Publisher Full Text | Free Full Text | F1000 Recommendation

144. F Düfer $\mathrm{M}, \mathrm{Hörth} \mathrm{K}$, Wagner $\mathrm{R}$, et al:: Bile acids acutely stimulate insulin secretion of mouse $\beta$-cells via farnesoid $X$ receptor activation and $K_{\text {ATP }}$ channel inhibition. Diabetes. 2012; 61(6): 1479-89.

PubMed Abstract | Publisher Full Text | Free Full Text | F1000 Recommendation

145. F Trabelsi MS, Daoudi M, Prawitt J, et al.: Farnesoid $\mathbf{X}$ receptor inhibits glucagon-like peptide-1 production by enteroendocrine L cells. Nat Commun. 2015; 6: 7629.

PubMed Abstract | Publisher Full Text | Free Full Text | F1000 Recommendation

146. Bäckhed $F$, Ding $H$, Wang $T$, et al:: The gut microbiota as an environmental factor that regulates fat storage. Proc Natl Acad Sci U S A. 2004; 101(44): 15718-23.

PubMed Abstract | Publisher Full Text | Free Full Text

147. F Liou AP, Paziuk M, Luevano JM Jr, et al.: Conserved shifts in the gut microbiota due to gastric bypass reduce host weight and adiposity. Sci Trans Med. 2013; 5(178): 178ra41.

PubMed Abstract | Publisher Full Text | Free Full Text | F1000 Recommendation

148. F Tremaroli V, Karlsson F, Werling M, et al:: Roux-en-Y Gastric Bypass and Vertical Banded Gastroplasty Induce Long-Term Changes on the Human Gut Microbiome Contributing to Fat Mass Regulation. Cell Metab. 2015; 22(2): 228-38.

228-38.
PubMed Abstract | Publisher Full Text | Free Full Text | F1000 Recommendation

149. $F$ Chen Z, Guo L, Zhang $Y$, et al:: Incorporation of therapeutically modified bacteria into gut microbiota inhibits obesity. J Clin Invest. 2014; 124(8): 3391-406. PubMed Abstract | Publisher Full Text | Free Full Text | F1000 Recommendation

150. Vidal J, Jiménez A, de Hollanda A, et al.: Metabolic Surgery in Type 2 Diabetes: Roux-en-Y Gastric Bypass or Sleeve Gastrectomy as Procedure of Choice? Curr Atheroscler Rep. 2015; 17(10): 58

PubMed Abstract | Publisher Full Tex 


\section{Open Peer Review}

\section{Current Peer Review Status:}

\section{Editorial Note on the Review Process}

Faculty Reviews are review articles written by the prestigious Members of Faculty Opinions. The articles are commissioned and peer reviewed before publication to ensure that the final, published version is comprehensive and accessible. The reviewers who approved the final version are listed with their names and affiliations.

\section{The reviewers who approved this article are:}

\section{Version 1}

\section{Mario Musella}

Division of Video-assisted Gastric Surgery, Federico II University of Naples, Naples, Italy

Competing Interests: No competing interests were disclosed.

\section{Alfonso Torquati}

Center for Weight Loss and Bariatric Surgery, Department of General Surgery, Rush University Medical Center, Chicago, IL, USA

Competing Interests: No competing interests were disclosed.

The benefits of publishing with F1000Research:

- Your article is published within days, with no editorial bias

- You can publish traditional articles, null/negative results, case reports, data notes and more

- The peer review process is transparent and collaborative

- Your article is indexed in PubMed after passing peer review

- Dedicated customer support at every stage

For pre-submission enquiries, contact research@f1000.com

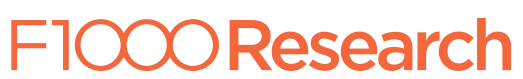

